Corrigendum

\title{
Corrigendum to "Lichenometric dating: Science or pseudo-science?" [Quaternary Research 83 (2015) 1-12]
}

\author{
Gerald Osborn $^{\mathrm{a}, *}$, Daniel McCarthy $^{\mathrm{b}}$, Aline LaBrie ${ }^{\mathrm{c}}$, Randall Burke $^{\mathrm{d}}$ \\ a Department of Geoscience, University of Calgary, Calgary T2N1N4, Canada \\ b Department of Earth Sciences, Brock University, St. Catharines, Ontario L2S 3A1, Canada \\ c Canadian Natural Resources Ltd., 2500, 855 2nd Street SW, Calgary, Alberta T2P4J8, Canada \\ d 1705, 700 9th Street SW, Calgary, Alberta T2P2B5, Canada
}

In the section "Is there any evidence that lichenometry works?" in our paper we claim that Young et al. (2009) incorrectly transcribed a lichen growth curve from Solomina and Calkin (2003), when they used it in the Alaska Range. The error is actually ours, as we based that point of discussion on the Brooks Range curve from Solomina and Calkin (2003) rather than the central Alaska curve that Young et al. actually used. There was no erroneous transcription, and we apologize to Nicolas Young and his coauthors. The last sentence in the paragraph in question should read "We conclude that the correspondence of ${ }^{10} \mathrm{Be}$ ages and lichenometric ages in this case is a stroke of lucky coincidence".

\section{References}

Solomina, O., Calkin, P., 2003. Lichenometry as applied to moraines in Alaska, U.S.A., and Kamchatka, Russia. Arctic Antarctic and Alpine Research 35, 129-143.

Young, N.E., Briner, J.P., Kaufman, D.S., 2009. Late Pleistocene and Holocene glaciation of the Fish Lake valley, northeastern Alaska Range, Alaska. Journal of Quaternary Science 24, 677-689. 